
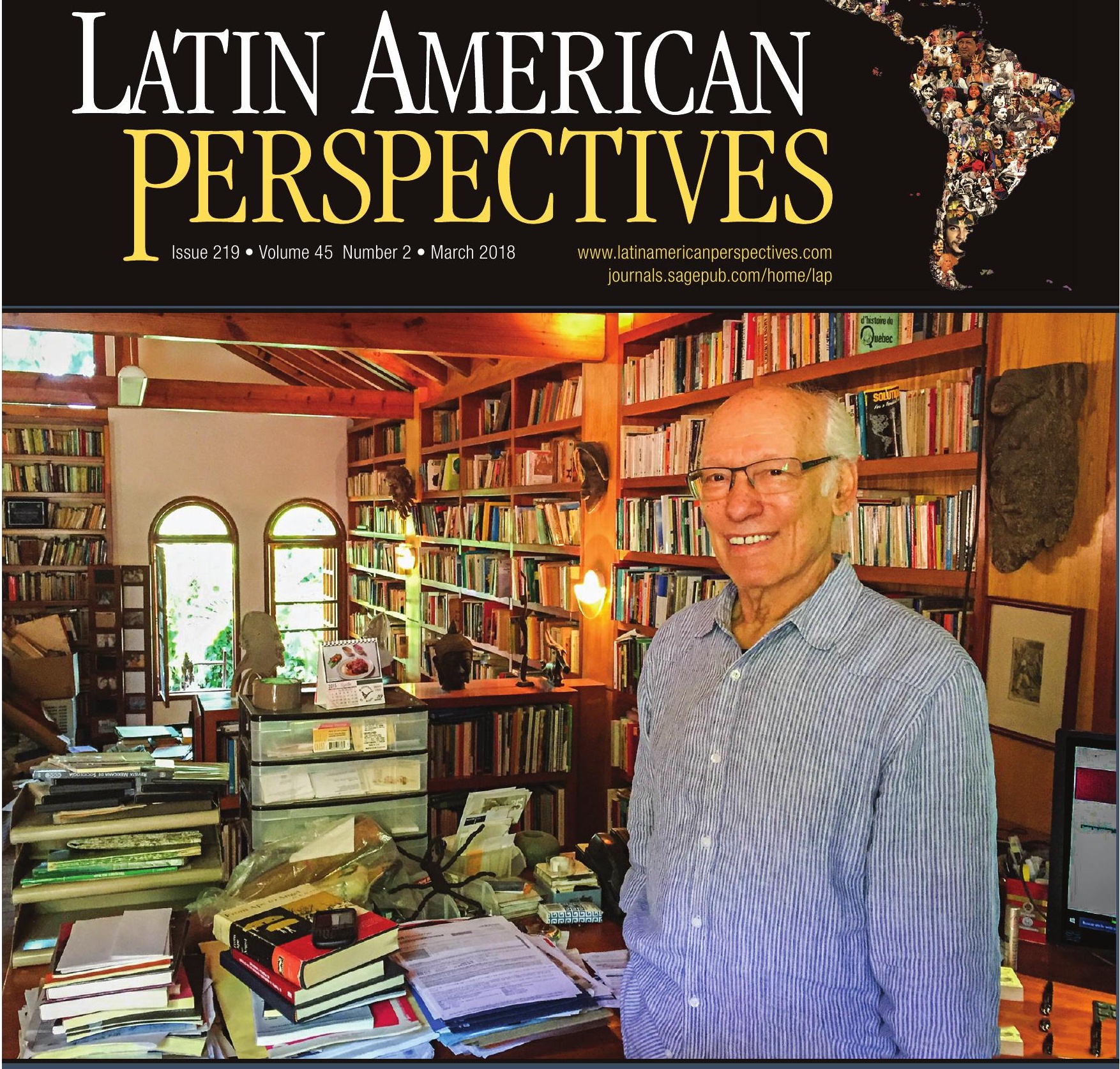

Freeing Latin America from Erroneous Theses

Photo $\odot$ José M. Morales, courtesy of the Colegio de México

Rus

Preface

Alvarado

Chew

Stavenhagen

Introductions

Barrientos

From Sociological Interpretation to Political Science

Cabalé and Rodríguez

Progress and Development in Latin America

Ramírez

Latin America's Domestic Market and Capitalism
Rodríguez

"Seven Erroneous Theses" and Mexican Anthropology

Loza

Stavenhagen and the Nation

Granada-Cardona

Alternatives for Latin American

Integration

Robles

"Erroneous Theses" and the Maquiladora Industry

Jiménez-Bandala

Verification of the Seven Theses in

Mexico
Canedo

Change in Bolivia and "Seven Erroneous Theses"

Lima

Notes by a Brazilian Translator

Chazarreta

Argentine Agrarian Social Structure

Torre

Racial Mixing and National Integration

Fernández

Indigenous Intellectuals in Ecuador

Book Review 


\section{LATIN AMERICAN PERSPECTIVES}

\section{A Journal on Capitalism and Socialism}

\section{COLLECTIVE OF COORDINATING EDITORS}

Responsible for journal decisions and policies.

\section{Ronald H. Chilcote, Managing Editor, University of California, Riverside}

William Bollinger, California State University, Los Angeles Donald Bray*, California State University, Los Angeles Marjorie Bray, California State University, Los Angeles Rosalind Bresnahan, San Bernardino, California Frances B. Chilcote, Laguna Beach, California Tomás Crowder-Taraborrelli, Soka University of America Jean Hostetler Díaz, Riverside, California

Armando González-Cabán, University of California, Riverside Timothy F. Harding*, California State University, Los Angeles Richard Harris, California State University, Monterey Bay
Jennifer Hughes, University of California, Riverside George Leddy, Los Angeles Valley College

Sheryl Lutjens*, California State University, San Marcos Rhonda Neugebauer, University of California, Riverside Jonathan Ritter, University of California, Riverside Jan Rus*, CESMECA, San Cristóbal, Mexico Ward Schinke, Riverside Community College Paulo Simões, California State University, Fullerton Miguel Tinker Salas*, Pomona College Kristi M. Wilson, Soka University of America

* On leave, unable to attend editorial meetings

\section{ASSOCIATE EDITORS}

Closely associated with the collective but unable to attend editorial meetings.

Ralph Armbruster-Sandoval, University of California, Santa Barbara

Dolores Paris, El Colef, Tijuana, Mexico

William Avilés, University of Nebraska at Kearney

Bernadete Beserra, Universidade Federal de Ceará, Brazil

Julie Charlip, Whitman College

Gary Dymski, University of California, Riverside

Alberto García, California State University, Northridge

Derrick Hindery, University of Oregon

Gary Hytrek, California State University, Long Beach

Mônica Dias Martins, Universidade Estadual de Ceará, Brazil

Stephanie Moore, Peruvian Oral History Project

Richard Potter, American Jewish University

Cecilia MacDowell Santos, University of San Francisco

Richard Stahler-Sholk, Eastern Michigan University

Steven C. Topik, University of California, Irvine

Laura Velasco Ortiz, El Colef, Tijuana, Mexico

Clare Weber, California State University, Dominguez Hills

Russell White, Kent, Washington

Heather Williams, Pomona College

Tamar Diana Wilson, San José de Cabo, Mexico

\section{HONORARY EDITORS}

In recognition of distinguished service over many years.

Atilio Borón

Norma Chinchilla

James Cockcroft

Héctor Díaz-Polanco

Joel C. Edelstein

Adolfo Gilly

Martha Giménez
Georg M. Gugelberger
Nora Hamilton
Dale Johnson
Susanne Jonas
James Levy

\section{PARTICIPATING EDITORS}

Hobart A. Spalding, Jr.

Steven Stern

Edelberto Torres-Rivas

Mary K. Vaughan

Steve Volk

Hilbourne Watson

Fully involved in reading manuscripts, organizing, and active in journal affairs.

Paul Almeida, University of California, Merced

Miguel A. Altieri, University of California,

Berkeley

Álejandro Álvarez Béjar, UNAM, Mexico

Thomas Angotti, CUNY, New York

Ricardo Antunes, UNICAMP, Brazil

Robert Austin, Chile

Florence Babb, The University of North

Carolina at Chapel Hill

David Barkin, UAM-Xochimilco, Mexico

Marc Becker, Truman State University

Emelio Betances, Gettysburg College

Armando Boito, UNICAMP, Brazil

Barry Carr, La Trobe University, Australia

Julio Carranza Valdés, UNESCO, Guatemala

James Cypher, Universidad Autónoma de Zacatecas, Mexico

Raúl Delgado Wise, Universidad Autónoma de Zacatecas, Mexico

Carmen Diana Deere, University of Florida

Haroldo Dilla, Instituto de Estudios

Internacionales de la Universidad

Arturo Prat, Chile

Elizabeth Dore, University of Southampton,

United Kingdom

Paul Dosh, Macalester College

Alex Dupuy, Wesleyan University

Susan Eckstein, Boston University

Steve Ellner, Universidad de Oriente,

Venezuela

Nicole Fabricant, Towson University

Linda C. Farthing, La Paz, Bolivia

Associate Managing Editors:

Film Review Editors:

Coordinating Secretary:

Book Review Editor:
Adriela Fernández, Purdue University

Marco A. Gandásegui, CELA, Panama

James N. Green, Brown University

Jawdat Abu El Haj, Universidade Federal de Ceará, Brazil

John Hammond, CUNY, New York

Neil Harvey, New Mexico State University,

Las Cruces

Daniel Hellinger, Webster University

Rafael Hernández, ICAIC, Cuba

Rosalva Aída Hernández Castillo, CIESAS, Mexico

Clara Irazábal, University of Missouri-

Kansas City

Daniela Issa, École des Hautes Études en

Sciences Sociales (EHESS), Paris, France

Stephen Lewis, California State University. Chico

João Roberto Martins Filho, Universidade Federal de São Carlos, Brazil

Adam Morton, The University of Sydney, Australia

Sara Motta, The University of Newcastle, Australia

Ronaldo Munck, Dublin City University,

Ireland

Nemer E. Narchi, El Colegio de Michoacán, Mexico

Mercedes Olivera Bustamante, CESMECA-

UNICACH, San Cristóbal, Mexico

Kemy Oyarzun, Universidad de Chile, Chile
Tânia Pellegrini, Universidade Federal de São Carlos, Brazil

Anthony Pereira, King's College London, United Kingdom

Daniel Polk, Morongo Valley, California

Pablo Pozzi, University of Buenos Aires, Argentina

Angel Quintero Rivera, CEREP, San Juan, Puerto Rico

Bernardo Ricupero, Universidade de São

Paulo, Brazil

William Robinson, University of California Santa Barbara

Alfredo Saad Filho, SOAS University of

London, United Kingdom

Arturo Santamaría Gómez, Universidad

Autónoma de Sinaloa, Mexico

Verónica Silva, UNAM, Mexico

Boaventura de Sousa Santos, Universidade de Coimbra, Portugal

Luís Suárez Salazar, Unión de Escritores y Artistas de Cuba, Cuba

Anthony Spanakos, Montclair State University

Harry Vanden, University of South Florida

Carlos Vilas, Buenos Aires, Argentina

Roberta Villalón, St. John's University

Jeffery R. Webber, Queen Mary University

of London, United Kingdom

Cliff Welch, Universidade Federal de São

Paulo, Brazil

Kevin A. Young, University of

Massachusetts, Amherst

\section{STAFF}

Marjorie Bray Rosalind Bresnahan George Leddy Tomás Crowder-Taraborrelli Kristi M. Wilson

Aiskell Román George Leddy
Book Review Coordinator: Manuscript Coordinator: Manuscript Editor: Photography Editor: Facebook: Social Media Coordinator: Podcast Host:
Julie Nogueda Frances B. Chilcote Barbara Metzger James Lerager Fátima Ruiz Arman Azed Alexander Scott 


\section{Latin American Perspectives}

Issue 219 MaRch 2018

Volume 45 Number 2

FREEING LATIN AMERICA FROM ERRONEOUS THESES

Issue Editors: Arturo Alvarado, Serena Chew Plascencia, and Jan Rus

Contents

Preface

The Legacy of Rodolfo Stavenhagen (1932-2016): Linking Critical Scholarship and Social Justice

JAN RUS $\ldots \ldots \ldots \ldots \ldots \ldots \ldots \ldots \ldots \ldots \ldots \ldots \ldots \ldots \ldots \ldots \ldots \ldots \ldots$

The Seven Erroneous Theses $\ldots \ldots \ldots \ldots \ldots \ldots \ldots \ldots \ldots \ldots \ldots$

\section{INTRODUCTIONS}

Validity, Change, and the Reinvention of Rodolfo Stavenhagen's

"Seven Erroneous Theses about Latin America": Debate over the

Pursuit of Modernity

ARTURO ALVARADO . . . . . . . . . . . . . . . . . . . .

50 Years of "Seven Erroneous Theses about Latin America": Perspectives and Challenges for Latin American Theory and Practice

SERENA CHEW PLASCENCIA ..................... 35

"Seven Erroneous Theses" 50 Years Later

RODOLFO STAVENHAGEN . . . . . . . . . . . . . . . .

\section{Articles: Theoretical Approaches}

From Sociological Interpretation to Political Science

FERNANDO BARRIENTOS DEL MONTE. ...............

Progress and Development: One and the Same in Latin America?

ELIZABETH CABALÉ MIRANDA AND

GABRIEL MODESTO RODRÍGUEZ PÉREZ DE AGREDA . . . . . . .

Latin America's Domestic Market and the Maintenance of Capitalism BERENICE PATRICIA RAMÍREZ LÓPEZ . . . . . . . . . . . .

"Seven Erroneous Theses about Latin America" and the Emergence of a

New Mexican Anthropology

EMANUEL RODRÍGUEZ DOMÍNGUEZ . . . . . . . . . . . .

Stavenhagen and the Nation: Ethnicity, Community, and Political Project

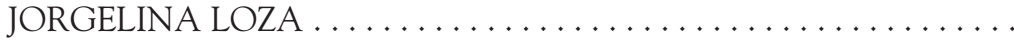

Alternatives for Latin American Integration: Beyond Racial Fusion and Multiculturalism 


\section{Articles: National Perspectives}

Received Wisdom: Stavenhagen's “Erroneous Theses” and the Mexican Maquiladora Industry MARÍA DEL ROSARIO FÁTIMA ROBLES ROBLES . . . . . . . . . . . 119

Development in Southern Mexico: Empirical Verification of the "Seven Erroneous Theses about Latin America" CARLOS ALBERTO JIMÉNEZ-BANDALA . . . . . . . . . . . . . . 129

Bolivia and Its Transformations in the Light of "Seven Erroneous Theses about Latin America"

"Seven Theses": Notes by a Brazilian Translator in the Twenty-first Century ROBERTO LIMA . . . . . . . . . . . . . . . . . . . . . . . . .

Applying Stavenhagen's Analytical Approach to Research on Argentine Agrarian Social Structure

ADRIANA CHAZARRETA

Racial Mixing and National Integration in Latin America: The Return of Racial Differences in Mexico and Brazil EDUARDO TORRE CANTALAPIEDRA

Indigenous Intellectuals in Contemporary Ecuador: Encounters with

"Seven Erroneous Theses about Latin America"

BLANCA SOLEDAD FERNÁNDEZ

\section{Book ReVIEW}

The Latin American Council of Social Sciences and Contemporary

Latin American Thought

MARCOS ANTONIO DA SILVA AND

LUCIMARA INÁCIO DO PRADO DA SILVA 
Latin American Perspectives (LAP) is a theoretical and scholarly journal for the discussion and debate on the political economy of capitalism, imperialism, and socialism in the Americas. The authors, however-not LAP or SAGE Publishing—are responsible for their own views, sources of information, writing style, and so on. Our objective is to encourage class analysis of sociocultural realities and political strategies to transform Latin American sociopolitical structures. We make a conscious effort to publish a diversity of political viewpoints, both Marxist and non-Marxist perspectives, that have influenced progressive debates in Latin America. Top priority will be given to articles that strike directly at the most important theoretical issues, particularly subjects that have received inadequate discussion or that are in sharp dispute. We also attempt to encourage the work of relatively "unknown" students and scholars and to bring the work of Latin American scholars to the English-speaking world. LAP welcomes strong views as long as they are backed by cogent arguments, are grounded in Latin American reality, and are written to be comprehensible to a wide audience. Readers' criticism, comments, and proposals are welcomed.

Manuscript Submission and Review Process: Manuscripts of up to 8,000 words can be submitted in English, Spanish or Portuguese and should be sent as Word documents to lap@ucr.edu. Upon submissions, please include an abstract of 150 words, 5 keywords, and current biographical and contact information. LAP also publishes book review essays, film reviews, and occasional photo essays. The LAP website (http://latinamericanperspectives.com/publish-in-lap-overview/) provides complete information on manuscript submission and review, including current Calls for Manuscripts, manuscript specifications, LAP Style Guidelines, book review, artwork, and photo guidelines, and description of the review and copy editing processes.

\section{LAP is on Social Media!}

Facebook: http://www.facebook.com/LAPerspectives

Twitter: http://twitter.com/LAPerspectives

Pinterest: http://pinterest.com/LAPerspectives

Linkedin: http://www.linkedin.com/in/LAPerspectives

Blog: http://laperspectives.blogspot.com/

Website: www.latinamericanperspectives.com

Latin American Perspectives (ISSN 0094-582X) (J273) is published bimonthly—in January, March, May, July, September, and November-by SAGE Publishing, 2455 Teller Rd., Thousand Oaks, CA 91320 on behalf of the Latin American Perspectives Editorial Collective, P.O. Box 5703, Riverside, CA 92517-5703. Periodicals postage paid at Thousand Oaks, California, and at additional mailing offices. POSTMASTER: Send address changes to Latin American Perspectives, c/o SAGE Publishing, 2455 Teller Road, Thousand Oaks, CA 91320.

Copyright $\odot 2018$ by Latin American Perspectives. All rights reserved. No portion of the contents may be reproduced in any form without written permission from the publisher.

Subscription Information: All subscription inquiries, orders, back issues, claims, and renewals should be addressed to SAGE Publishing, 2455 Teller Road, Thousand Oaks, CA 91320; telephone: (800) 818-SAGE (7243) and (805) 499-0721; fax: (805) 375-1700; e-mail: journals@sagepub.com; website: journals.sagepub.com. Subscription Price: Institutions: \$890; Individuals: \$74. For all customers outside the Americas, please visit http://www.sagepub.co.uk/customerCare.nav for information. Claims: Claims for undelivered copies must be made no later than six months following month of publication. The publisher will supply replacement issues when losses have been sustained in transit and when the reserve stock will permit.

Copyright Permission: To request permission for republishing, reproducing, or distributing material from this journal, please visit the desired article on the SAGE Journals website (journals.sagepub.com) and click "Permissions." For additional information, please see www.sagepub.com/journalspermissions.nav.

Advertising and Reprints: Current advertising rates and specifications may be obtained by contacting the advertising coordinator in the Thousand Oaks office at (805) 410-7772 or by sending an e-mail to advertising @ sagepub.com. To order reprints, please e-mail reprint@sagepub.com. Acceptance of advertising in this journal in no way implies endorsement of the advertised product or service by SAGE, the journal's affiliated society(ies), or the journal editor(s). No endorsement is intended or implied. SAGE reserves the right to reject any advertising it deems as inappropriate for this journal.

Change of Address: Six weeks' advance notice must be given when notifying of change of address. Please send old address label along with the new address to the SAGE office address above to ensure proper identification. Please specify the name of the journal. 


\title{
Latin America's Domestic Market and the Maintenance of Capitalism
}

\author{
by
}

\author{
Berenice Patricia Ramírez López \\ Translated by \\ Mariana Ortega Breña
}

\begin{abstract}
Rodolfo Stavenhagen, in his classic essay "Seven Erroneous Theses about Latin America," addressed the narrow domestic market, indicating that it was basically a matter of income distribution. It has become clear that the priorities of the Latin American ruling class are focused on the world market rather than the local-national one. During the past 40 years, this class has become more determined to play the role of intermediary, taking its place in the field of trade, commerce, and mainly speculative financial transactions that allow for immediate returns. It does not promote domestic productive investment or the strengthening of education, innovation, or development technology and therefore secure and protected employment. Inequality has increased across the region, along with increasing labor precarity (notably informal employment), and thus the internal market reflects productive and social segmentation and inequality.
\end{abstract}

Rodolfo Stavenhagen en su clásico ensayo acerca de las 7 tesis equivocadas sobre América Latina aborda la cuestión del estrecho mercado interno señalando que es esencialmente una cuestión de distribución del ingreso. Ha quedado claro y más en el periodo neoliberal que la prioridad de la clase dominante latinoamericana está en el mercado mundial, no en lo local-nacional. Queda demostrado que en los últimos cuarenta años ha asumido con más determinación su papel de intermediaria, interesada en situarse en el ámbito del intercambio, del comercio y de las transacciones financieras, principalmente especulativas, que le permitan rentabilidades inmediatas. No promueve en el mercado interno las inversiones productivas ni el fortalecimiento de la educación ni la innovación ni el desarrollo tecnológico y por lo tanto el empleo seguro y protegido. La región muestra que la desigualdad se ha acentuado, que se acompaña de una creciente precarización del empleo, que el empleo informal es lo que más destaca y que por lo tanto el mercado interno expresa la segmentación y desigualdad productiva y social.

Keywords: Labor market, Informal employment, Internal market, Inequality

Berenice Patricia Ramírez López is head researcher of the Research Unit in Development and Public Policy of the Instituto de Investigaciones Económicas, Universidad Nacional Autónoma de México. She also teaches in the university's Latin American studies and economics postgraduate programs. Her research focuses on development and social policy, social security and the labor market, and pensions and labor informality. Mariana Ortega Breña is a freelance translator based in Canberra, Australia. 
Economists and sociologists speak constantly about the need of incorporating the "backward" subsistence peasants into the money economy in order to strengthen the internal market and further economic development. Yet nowhere in Latin America is the gap between rich and poor greater than in the cities, where the desperately poor "marginal" urban population of the shantytowns is growing rapidly. If the internal market were indeed the driving force of Latin America's bourgeoisie, Mexico's capitalists would not be seeking, as they are, investment opportunities in Central America, or Brazil's in Paraguay and Bolivia; they would not be exporting millions of dollars a year to the security of American and European banks.

The academic and political discussion that gave rise to the publication and subsequent debate about Stavenhagen's "Seven Erroneous Theses about Latin America" (1968 [1965]) sought to show that the supposed Latin American duality was not merely an expression of backwardness and therefore could not be overcome simply through economic growth. Nor was it just the expression of a structural heterogeneity that could presumably be eliminated through industrialization (Cueva, 1990; Cardoso and Faletto, 1987; Furtado, 1991; Ocampo, 2015). A noteworthy characteristic of the past three decades has been the fragmented nature of the Latin American labor structure as seen in the high rates of informal employment. In addition to the employment generated by households as economic units and the independent activities better known as "self-employment," there has been an increase in jobs lacking social security or employee benefits through the use of short-term contracts, independent contractors, or subcontractors, which now account for $30-75$ percent of Latin American employment. Employment dynamics, income levels, and wages are both cause and evidence of the deepening of inequality across the region. In the international division of labor, Latin America continues to provide raw materials, consumer goods, and manufacturing processes, mainly assembly (maquiladoras). The search for new areas for investment, profit, and therefore accumulation has been accompanied by dispossession of territory, public assets, knowledge, and ancestral and even cultural practices. However, the expected growth of waged work in an ascending spiral of secure employment with social protections has not materialized; to the contrary, precarity and informality have increased. The following analysis of these developments will include a brief overview of the world of labor, occupations, and income in Latin America, a description of the Latin American domestic market and its function, and a discussion of the challenges of Latin American capitalism.

\section{LABOR, OCCUPATIONS, AND INCOME IN LATIN AMERICA}

We are witnessing radical changes in the capital/labor relationship. Multiple factors have increased pressure on waged workers: low economic growth, new technologies that affect the organization of work, and increased competition associated with the concentration of capital and the growth of monopoly power. Latin American growth has been uneven. The region experienced dynamic 
TABLE 1

Rates of Nonagricultural Informal

Employment, 2013

\begin{tabular}{ll}
\hline Guatemala & 73.6 \\
Honduras & 72.8 \\
El Salvador & 65.6 \\
Peru & 64.0 \\
Paraguay & 63.8 \\
Colombia & 54.4 \\
Mexico & 53.8 \\
Dominican Republic & 51.2 \\
Ecuador & 49.3 \\
Average & 46.8 \\
Argentina & 46.8 \\
Panamá & 40.4 \\
Brazil & 36.5 \\
Uruguay & 33.1 \\
Costa Rica & 30.7 \\
\hline
\end{tabular}

Source: ILO (2016).

growth during the early years of the twenty-first century until 2008, but this was mainly limited to the Southern Cone. The International Labor Organization indicates growth of more than 40 percent in the decade preceding 2012, reducing poverty from 44 percent to 28 percent (ILO, 2014a: 11). Informality, however, dropped only from 50 percent to 47 percent ILO, 2014a: 13) (Table 1). To explain this we must consider the characteristics of the growth of wage labor: According to the ILO (2016: 14), between 1991 and 2010 the unemployment rate rose from 8 percent to nearly 11 percent but then fell sharply to 6.3 percent in 2013 . However, starting in 2014 economic growth and job creation weakened. The average growth of Latin America contrasts with that of Mexico, where the growth of the gross domestic product (GDP) in 1994-2015 was 2.5 percent (ECLAC, 2016: 16) The growth rate for waged work in 2005-2016 was an average of 2.5 percent while that of unemployment was 4 percent; however, informal employment (home-based employment and employment that does not provide social security) accounted for 58 percent of the urban employed population (INEGI, 2016).

The loss of employment and social security benefits, which once provided workers with some stability, has weakened most Latin American labor markets. Working conditions are increasingly precarious because contracts cover shorter periods, there is more turnover, wages are lower, and there is no social security. Along with reduced collective hiring (union contracts covering groups of workers in a business or sector), more outsourcing, and the impact of new technologies that lead to new forms of labor organization (e.g., distance work, fragmented, task-specific work, and robotics), these working conditions are driving the growth of informal employment. The incentive to participate in global production chains is primarily the result of lower labor costs that translate into low wages and the increasing lack of labor rights.

Investment is still focused on the extraction of natural resources, assembly, primary sector products, and income from the services sector. Between 2000 
and 2015, jobs in occupations requiring highly skilled workers showed a limited increase, from 17.6 percent to 19.9 percent of total employment (ILO, 2016: 2 ). The trade and financial opening highlighted the differences among activities aimed at the foreign market, driven by products and raw materials tradable on the stock market, and a lack of domestic industrial and investment policies that deepened the abandonment and fragmentation of the internal market. This focus on an export model has had little impact on job creation because of the high proportion of imported inputs and components in the region's exports. In Mexican industries such as electronics, in which many companies operate under the maquila model, the national value added of exports is less than 10 percent of total value (ECLAC, 2016: 17).

High profit rates are maintained more by low wage costs than by increased labor productivity. It is striking that labor productivity in Mexico registered a growth of 0.9 percent between 2000 and 2014 (significantly less than that of the United States [2.1 percent]) (ECLAC, 2016: 17). The labor and social fragmentation of capitalism favors profitability and income for its hegemonic fraction. The concentration of wealth represented by the large industrial and financial conglomerates requires some direct, productive and therefore socially protected work, but it also needs the indirect, low-paying, precarious and informal jobs that this creates to achieve its incorporation into the world market and provide income options for those who cannot take part in the limited formal wage structure. The latter is restricted in an attempt to maintain profit levels and support the fragmented domestic markets, characterized by a variety of activities that are highly dependent on the household as an economic unit. In the absence of an increase in waged employment that provides both labor and social security and expresses the real relationship between labor and capital, the household, which owns assets and resources built by several generations (and, in some cases, several families), provides primarily a subsistence income based on the work of family members. This includes activities and services such as workshops, kitchens for food production and distribution, improvised home warehouses that store goods that will be sold in public space, and selfemployment activities that turn the home into an office, studio, company headquarters, etc. When not reported to revenue authorities, these activities add to the informal sector, which includes employers, waged workers, and workers who work for tips or payment in kind.

During the 1960s, informality was seen as a phenomenon of urbanization and migration from the countryside to the city that would be resolved through the increase in waged labor that would result from modernization and industrialization. However, neither has the growth of waged labor met the employment needs of the economically active population nor is the number of informal and unemployed workers merely an expression of the industrial reserve army. Capitalism works in our countries by keeping one-third or more of the population in formal rather than real subsumption of labor to capital. ${ }^{1}$ This is not a temporary or conjunctural phenomenon, and it is also starting to happen in the regions of highly industrialized countries that are not connected to globalization or that, while highly globalized, attract a migrant workforce whose reproduction takes place under simple relations of production. $^{2}$ 
Thus, in a situation of reduced public and private investment in the domestic market that could have generated productive, entrepreneurial, and service activities to strengthen small and medium-sized enterprises, what has emerged instead is the strong participation of households as economic units. There are obviously institutional deficits, and the state has assumed a distinctly liberal role, attending only to extreme poverty outside the market circuit. However, dependency has become more pronounced, and alternative models of social reproduction require the combination of management of the resources that finance growth with distributive policies that promote the creation of jobs with social security and increased wages and social policies that bring about redistribution, beginning with reform of the tax system through progressive real estate transfer taxes.

Mexico is a clear example of uneven regional growth: its annual growth rate has been less than 2 percent for the past 30 years, 46.2 percent of the population is below the poverty line (Consejo Nacional de Evaluación de la Política Social, 2015: 14), and 58 percent of the employed population works in the informal sector (INEGI, 2016). If we compare it with Bolivia and Brazil, two countries that have sought to transform their development models during the past three decades, we find that Bolivia's growth rate was 4.5 percent for 2003-2008, 4.2 percent for 2009-2011, and 6 percent for 2012-2013, while Brazil's was 4.2, 3.3, and 1.7 percent during these periods (ECLAC, 2014b: 84). Although the nation sizes and economies are very different, poverty levels, at least as recorded in surveys of household income and spending, have declined in all these countries. Between 2004 and 2011 poverty in Bolivia decreased from 63 percent to 36.3 percent and poverty in Brazil from 36.4 percent to 18.6 percent (ECLAC, 2014a: 17, Table 1). From 1989 to 2011 the income share of the tenth decile in Bolivia declined from 38.2 percent to 26.4 percent while increasing for the second to fifth deciles (ECLAC, 2014a: 118 annex, Table 2A.1]). In Mexico the share of the tenth decile decreased from 36.6 percent in 1989 to 31.4 percent in 2012. Brazil recorded a decrease from 43.9 percent in 1990 to 38.9 in 2013. Despite these results, informal employment has continued to grow. In Bolivia, 71 percent of the employed population older than 15 worked in the informal sector in 2009, increasing to 87 percent for young people aged 15 to 24 (ILO, 2013: 239 annex, Table 22).

In the case of Bolivia, the contradictions accumulated throughout the history of nation building and the evolution of the social formation, heightened by the political decision of social movements to bring about change, brought the Evo Morales government to power. This change in the political system has resulted in a transformation of both the economic model and social reproduction, but it is still based on the structure of production established in the second half of the nineteenth century. The financing of economic growth continues to be based on the extraction of natural resources (minerals and gas) because modifying funding sources or encouraging investment in other sectors linked to the internal market is a very long-term process. This is especially the case since, under neoliberalism, the opening up of trade and finance in Latin America meant that profit maximization involved investment in the dynamic sectors that contributed to global accumulation through minimal labor costs from low pay, lack of social security, and precarious and short-term jobs. 
TABLE 2

Real Minimum Wage Index, 2005-2013

$($ Year $2000=\mathbf{1 0 0})$

\begin{tabular}{lrr}
\hline Country & 2005 & 2013 \\
\hline Bolivia & 106.3 & 174.4 \\
Brazil & 128.5 & 202.7 \\
Chile & 113.4 & 138.7 \\
Colombia & 107.2 & 121.2 \\
Costa Rica & 99.9 & 115.7 \\
Dominican Republic & 96.3 & 100.2 \\
Ecuador & 101.9 & 153.6 \\
El Salvador & 90.7 & 102.6 \\
Guatemala & 115.4 & 124.2 \\
Honduras & 121.6 & 276.5 \\
Mexico & 101.3 & 101.8 \\
Nicaragua & 118.0 & 202.2 \\
Panama & 104.5 & 109.1 \\
Paraguay & 104.4 & 101.2 \\
Peru & 105.2 & 135.6 \\
Uruguay & 132.1 & 256.1 \\
Venezuela & 108.6 & 112.6 \\
\hline
\end{tabular}

Source: ILO (2014a), based on national data per country.

Between 2009 and 2013, 11 out of 14 Latin American countries managed to reduce their rates of nonagricultural informality (ILO, 2014b: 53-79). (In the Dominican Republic, Colombia, and Mexico, the rate increased.) The most prominent examples of decrease were Costa Rica (from 43.6 percent to 30.7 percent), Ecuador (from 60.5 percent to 49.3 percent), Paraguay (from 70 percent to 63.8 percent), and Brazil (from 41.7 percent to 36.5 percent). This decline may be associated with GDP and, particularly, investment growth. Ecuador's gross fixed capital formation, for example, rose from 18.4 percent of the GDP in 1980-1989 to 27 percent in 2003-2010 (Manuelito and Jiménez, 2015). However, this relationship is not the only cause of the decrease in informal employment; in Costa Rica gross investment in fixed capital was lower than Ecuador's, increasing from 19.7 percent to 21.8 percent. Another factor appears to be wage levels. Between 10 and 15 percent of the employed Latin American population receives up to one minimum wage. Although we need more detailed analyses by country regarding the relationship between increase in the real minimum wage and formal employment, it is clear that countries with less informality have experienced significant wage growth. The clearest example is Uruguay, with 33 percent informal employment and an increase in the index of the real minimum wage from 132 to 256 in 2009-2013 (Table 2). Brazil and Bolivia, where the wage index went from 120.5 to 202.7 and from 106.3 to 174.4 , respectively, also stand out. The one country in which the minimum wage did not increase is Mexico. However, informal employment for the region remains an average of one-third of the labor force. Still other factors to be considered are the quality of employment and the degree of integration of the export and domestic markets. 


\section{THE LATIN AMERICAN DOMESTIC MARKET}

New methodologies designed to identify informal employment ${ }^{3}$ take two elements into account: the employing economic unit and employment status. As already noted, the fragmentation of the internal market has led to the household sector's producing, on average, one-third of employment, and this sector tends to have low productivity. If to this we add the unprotected employment (what Slavnic [2009] calls "informalization from above") that is part of Latin American labor, we can begin to understand the dimensions of informal employment. However, the labor dynamic is more complex, especially in social formations with a mostly indigenous population, whose work patterns, relationship with the land, collective and community action, and other cultural practices establish informality from below (Slavnic, 2009). These are social forms that often have not been touched by a direct capital-labor relationship, and therefore there are still large segments of the population that were not included in proletarianization or the construction of citizenship and therefore remain excluded from human and social rights.

The term "precarity" has become widespread because, upon analyzing employment conditions and wage levels, researchers can demonstrate that legally protected waged work is not on the rise. What is increasing is selfemployment and household-based employment and income-generating activities such as family workshops, informal commerce in the public space, the sale of any subsistence agricultural surplus, and domestic and personal care work. It is clear that household assets, often amassed under precarious conditions over several generations, are what holds the internal market together. In the case of Mexico, households generate 36 percent of employment. This, in addition to the amount of labor lacking social security in the formal sector, means that in the second trimester of 201657.2 percent of employment was informal (INEGI, 2016).

The construction of the domestic capitalist market is closely linked to proletarianization and an increase in waged workers. The free labor force is mainly the result of rural populations' being expelled from their lands and therefore requiring jobs and wages to cover their basic needs. This, plus the division of labor, is the principle underlying the growth and strengthening of the internal market. However, the contradictions of the capitalist system, the intense technological development, requiring fewer workers, and the concentration and centralization that produced domination by monopolies and transnational corporations eliminated the opportunity for free choice and free competition. This undercut the potential dynamic growth of waged labor that under the welfare state is supposed to enjoy social security and to constitute the basis for a free and competitive market.

In view of the dynamics of capitalist globalization and the global lack of employment, we must wonder what kind of vision prompts the leaders of the hegemonic nations, faced with the great need for food and only minimal levels of well-being, to promote conditional cash transfers that allow merely subsistence levels of consumption while their profitability is ensured by the polarized distribution of income and consumption by higher-income sectors. We must ask why the system does not allow for options that would include the 
revitalization of the domestic market as the result of a more equitable income distribution. Part of what we see in Latin America has to do with the opening up our national economies to the world market and the absence of sound states that represent the national interest. Incorporation into externally generated production processes has been prioritized; foreign investment is much sought after, along with trade that generates profits; profits are usually not reinvested or employed to support innovation or local creation. In other words, we perpetuate a colonialist mentality.

It has often been said that what Latin American countries need is more and better education. Undoubtedly, there are regions in which it is fundamental to promote basic quality education with up-to-date content. Examining informality and education, however, Levy and Székely (2016: 499) report:

We find that in Latin America there has been a slight reduction in labor informality associated mainly with the first effect: recent generations of workers with more schooling have lower informality rates than previous ones. In the case of Mexico we also observe that younger generations of workers have more years of schooling than previous ones; however, this has not translated into lower informal employment because of adverse labor market characteristics. Thus, even though Mexico has experienced faster educational progress than the average of the region, its progress in reducing informality has been nil.

They conclude: "Thus, while the assumption is that more schooling translates into less informality, the labor market may dilute or even reverse it" (502).

When we analyze Latin American labor markets, we also discover that social reproduction continues to show areas of simple reproduction that do not necessarily lead to increased valorization. This may be because of lack of options, but it may also be because its objective is not the accumulation and increased reproduction of capital. According to Wallerstein (2006: 28-31), instead of free workers who offer their labor power on the market we find a network of households with a division of activities. The household becomes an exploited subject that is functional for capitalism in that it may combine several kinds of workers and income sources: a salaried worker, a self-employed worker, a street vendor, a nonwaged worker, and a transfer payment recipient. Consumption is ensured and the domestic market remains fragmented. The problem, as I see it, is that policies that should increasingly address universal redistribution merely focus on ensuring a subsistence income rather than encouraging the creation of stable paid occupations with social security.

The households that in Latin American daily life coalesce into communities and cooperatives have a different logic from that of the capitalist market. They find a simple commercial relationship sufficient and privilege other expressions of sociability and relationships between humans and nature. They mistrust capitalist institutions not because they are unfamiliar with financial culture but because of the greed they represent. They participate in consumer and commercial practices and, although they are not wage earners, are immersed in expensive and risky credit plans. Additionally, their daily existence in a context of institutional weakness and political exclusion leads them to reproduce patterns of corruption, drawn into these dynamics by the struggle for spaces that once were public. 
The clear difference between a domestic market as a local space for the production and exchange of goods and services and one that is grounded in the growth of free labor and the generalization of wages ${ }^{4}$ allows a better understanding of the role of informality and precarity in system maintenance. First of all, such a system cannot provide the whole population with protected employment if it is to remain competitive in the world market. Secondly, a proper integration of the domestic market would involve opening up spaces for competition under equal conditions, thus eliminating the concentration and centralization represented by corporate conglomerates and transnational corporations. It is clear that the fragmentation of the internal markets of Latin American countries serves to maintain the inequality these societies experience.

\section{THE CHALLENGES OF LATIN AMERICAN CAPITALISM}

Analyses of Latin American development have focused on the following approaches: overcoming via modernization the dual structure that leads to poverty and marginalization, promoting state-led industrialization to transform the productive process in an equitable way, and allowing the market to determine via free trade, indiscriminate economic openness, and the prioritization of incorporation into world markets. In all these scenarios, informal employment remains prominent and even becomes more so. Slavnic (2009) has pointed out that the informal economy cannot be understood as separate and isolated from the economic system; informality exists to varying degrees in all types of social action. Like the formal economy, it must be addressed via demands for public policies that alleviate inequalities.

In a globalized world with a concentrated distribution of income and in countries that experience dependent relationships, the only way to sustain profitability seems to be to ensure a fragmented domestic market. Nonetheless, Latin American countries such as the Andean nations of Bolivia and Ecuador have attempted other forms of development, new forms of social organization that emphasize living well and a relationship between humans and nature that is environmentally sustainable. This has given rise to analyses that focus on new forms of production and a shift toward growth reduction. Others emphasize the recovery of indigenous peoples' worldviews and the defense and construction of public and common spaces. There are also those who have salvaged the concept of social capital and stress the importance of shared norms, knowledge, and rules for collective action (Ostrom and Ahn, 2003: 164). Adopting a different perspective on development entails the construction of sustainable production processes based on a relationship between humans and nature that transcends an exclusively utilitarian and commercial logic. Agriculture, crafts, culture, and community service should not be synonymous with backwardness but part of an inclusive social construction focused on human well-being and development.

The debate ahead of us is one between capitalist hegemony, based on consumption and waste, and a vision of sustainability and care of the environment and life as a whole. The great challenge is to give labor its proper place as a vital 
expression-a creative, transforming and liberating force. This will entail a long path of transformation including changes in ways of fulfilling needs, obtaining income, and creating collective projects that encompass labor, culture, recreation, and social and political action. This will be a long and rocky road, a challenge that requires broad participation.

\section{NOTES}

1. In formal subsumption, capital places particular forms of work under its control in the technological state in which it finds them and as they have developed from noncapitalist production conditions. Real subsumption is identified with a specifically capitalist mode of production and encompasses not just the individual worker but also social work and diverse labor capacities, allowing for valorization and constant accumulation (see Echeverría, 2005).

2. Production based on private ownership of the means of production and the personal work of producers, who produce articles intended for sale on the market. In a simple mercantile economy, the only commodities are the products of human labor, while in a capitalist one the labor force itself becomes a commodity (Borisov, Zhamin, and Makarova, 2009).

3. According to the ILO (2004), informal employment includes "own-account workers employed in their own informal sector enterprises; employers employed in their own informal sector enterprises; contributing family workers; members of informal producers' cooperatives; employees holding informal jobs in formal sector enterprises, informal sector enterprises, or as paid domestic workers employed by households; own-account workers engaged in the production of goods exclusively for own final use by their household" (if such production is a significant contribution to total household consumption).

4. "Says Mirabeau: ... 'The isolated, individual workshops, for the most part combined with the cultivation of smallholdings, are the only free ones.' The expropriation and eviction of a part of the agricultural population not only set free for industrial capital the workers, their means of subsistence and the materials of their labor; it also created the home market. ... And only the destruction of the rural domestic industry can give the home market of a country that extension and stability which the capitalist mode of production requires" (Marx, 1977 [1867]: 910-911).

\section{REFERENCES}

Borisov, E. F., V. A. Zhamin, and M. F. Makarova

2009 "Diccionario de economía política." http://www.eumed.net/cursecon/dic/bzm/p/ produccionms.htm (accessed July 2015).

Cardoso, F. H. and Enzo Faletto 1987 Dependencia y desarrollo en América Latina. Mexico City: Siglo XXI.

Consejo Nacional de Evaluación de la Política Social 2015 Medición de la pobreza en México y en las entidades federativas, 2014. Mexico City: CONEVAL. Cueva, Agustín 1990 El desarrollo del capitalismo en América Latina. Mexico City: Siglo XXI.

Echeverría, Bolívar 2005 La tecnología del capital: Subsunción formal y subsunción real del proceso de trabajo al proceso de valorización (extractos del manuscrito 1861-1863). Mexico City: Itaca.

ECLAC (Economic Commission for Latin America and the Caribbean)

2014a Economic Survey of Latin America and the Caribbean 2014: Challenges to Sustainable Growth in a New External Context. Santiago: ECLAC.

2014b Social Panorama of Latin America 2014. Santiago: ECLAC.

2016 "Productividad y brechas estructurales en México." http://repositorio.cepal.org/ bitstream/handle/11362/40165/1/S1600553_es.pdf.

Furtado, Celso

1991 La economía latinoamericana: Formación histórica y problemas contemporáneos. Mexico City: Siglo XXI. 
ILO (International Labor Organization)

2004 "Final report of the 17th International Conference of Labour Statisticians, Geneva, November 23 to December 3, 2003." http://www.ilo.org/wcmsp5/groups/public/— dgreports/—stat/documents/meetingdocument/wcms_087568.pdf.

2013 Trabajo decente y juventud en América Latina 2013: Políticas para la acción. Lima: ILO.

2014a "Twenty-first century challenges for the Americas: full and productive employment and decent work. Report of the Director General." http://www.ilo.org/wcmsp5/groups/ public/—ed_norm/—relconf/documents/meetingdocument/wcms_300402.pdf.

2014b "Thematic labour overview 1: transition to formality in Latin America and the Caribbean." http://www.ilo.org/wcmsp5/groups/public/_americas/_ro-lima/ documents/publication/wcms_314469.pdf.

2016 Studies on Growth with Equity: What Works-Active Labour Market Policies in Latin America and the Caribbean. Geneva: ILO.

INEGI (Instituto Nacional de Estadística y Geografía)

2016 Encuesta nacional de ocupación y empleo. Mexico City: INEGI.

Levy, Santiago and Miguel Székely

2016 “¿Más escolaridad, menos informalidad? Un análisis de cohortes para México y América Latina." El Trimestre Económico 83 (332): 499-548.

Manuelito, Sandra and Luis Felipe Jiménez

2015 "Rasgos estilizados de la relación entre inversión y crecimiento en América Latina, 1980-2012." Revista CEPAL, no. 115, 7-25.

Marx, Karl

1977 (1867) Capital Volume One. Translated by Ben Fowkes. New York: Random House Vintage Books.

Ocampo, J. A.

2015 "Los retos del desarrollo latinoamericano a la luz de la historia." Cuadernos de Economía 34 (66): 479-506.

Ostrom, Elinor and T. K. Ahn

2003 "Una perspectiva del capital social desde las ciencias sociales: capital social y acción colectiva." Revista Mexicana de Sociología 65 (1): 155-233.

Slavnic, Zoran

2009 "La informalización y la economía política de la reestructuración." Migración y Desarrollo 13 (2): 5-26.

Stavenhagen, Rodolfo 1968 (1965) "Seven fallacies about Latin America," pp. 13-31 in James Petras and Maurice Zeitlin (eds.), Latin America: Reform or Revolution?. New York: Fawcett.

Wallerstein, Immanuel 2006 Análisis de sistemas-mundo: Una introducción. Mexico City: Siglo XXI. 